\title{
EXPLORING THE LINKS BETWEEN TOURISM AND QUALITY OF INSTITUTIONS
}

\author{
Eva $M^{a}$ Buitrago Esquinas* \\ $M^{a}$ Ángeles Caraballo Pou** \\ Universidad de Sevilla
}

\begin{abstract}
This paper introduces a new perspective on the impacts of tourism on host communities by analyzing the links between tourism specialization and quality of institutions. Our research has two principal aims: firstly, to test the significance and sign of this relationship; and secondly, to explore the channels through which tourism could affect institutional quality. To this end, an econometric analysis is conducted using a sample of 92 countries over the period 1995-2014. The results indicate that there is a significant and positive association between tourism specialization and institutional quality. Moreover, this relation can be explained through three main channels: level of income, income inequality, and economic freedom.
\end{abstract}

Keywords: tourism impact, tourism specialization, quality of institutions, level of income, income inequality, economic freedom.

JEL Classification: Z32, O43.

\section{Explorando las relaciones entre especialización turística y calidad institucional}

\section{RESUMEN}

Este trabajo aporta una nueva perspectiva sobre los impactos del turismo analizando las relaciones entre la especialización turística de un país y la calidad de sus instituciones. La investigación plantea dos objetivos: (1) testar empíricamente la significatividad y signo de dichas relaciones y (2) explorar los canales a través de los que se producen. Realizamos un análisis econométrico para 92 países y 20 años. Los principales resultados indican la

Fecha de recepción: 12 de febrero de 2018

Fecha de aceptación: 20 de septiembre de 2018

* Departamento de Economía Aplicada III. Facultad de Ciencias Económicas y Empresariales. Universidad de Sevilla.Avda. Ramón y Cajal, 1.41018 SEVILLA (España).E-mail: esquinas@us.es

** Departamento de Economía e Historia Económica. Facultad de Ciencias Económicas y Empresariales. Universidad de Sevilla. Avda. Ramón y Cajal, 1.41018 SEVILLA (España).E-mail: mcaraba@us.es 
existencia de una asociación significativa y positiva entre turismo y calidad institucional que se produce principalmente a través de tres canales: nivel de renta, distribución de la renta y libertad económica.

Palabras clave: Impactos del turismo, especialización turística, calidad institucional, nivel de renta, distribución de la renta, libertad económica.

Acknowledgments: The research of the authors is partially supported by the Research Group "Research in Applied Economics" (SEJ258, Plan Andaluz de Investigación, Junta de Andalucía, Spain).

\section{INTRODUCTION}

This paper addresses the relationships between tourism specialization and quality of institutions at a country level. With this study, we intend to contribute to improving the understanding of the impacts of tourism activity on the destinations where this activity develops. The knowledge of these effects can help those responsible for tourism planning to establish those measures that encourage the positive effects and mitigate the negative ones.

There is no doubt that tourism affects many aspects of life of the local residents of tourist destinations and can become an important element of territorial development. However, the development of tourism is not without risk, as it can also be responsible for adverse effects on the community. The study of the impact of tourism therefore constitutes a topic that has been widely discussed in both the scholarly literature (Sinclair, 1998; Wall and Matthieson, 2006; Uysal et al., 2016 have all reviewed these studies) and in institutions (WTO, 2005; 2015).

There are several kinds of tourism impacts, all of which form part of an interrelated complex system. The majority of the studies tend to divide these impacts into three categories: (1) economic, (2) socio-cultural, and (3) environmental impacts; and these in turn can be either positive or negative. First, economic impacts include aspects such as increased investment and provision of jobs, improved income, and levying of additional tax revenues, but can also involve inflation and increases in the cost of living. Socio-cultural impacts cover elements such as greater recreation opportunities, opportunities for socializing with visitors, fostering cross-cultural understanding, and resurgence of traditional culture, but may also increase crime rates and changes in traditional cultures. Lastly, environmental impacts include increased environmental awareness, and preservation of natural and cultural resources, but can also imply crowding, pollution, vandalism, litter, and destruction of the local wildlife.

A proper planning of tourism activity requires the knowledge of the impact of tourism and understanding the mechanisms through which these impacts spread. This will help ensure that tourism development will lead to higher levels of quality of life of host communities.

Although the quality of institutions is one of the key elements for the improvement of the quality of life of a society (Kim and Kim, 2012), there is only a limited amount of scientific literature regarding the impacts of tourism on institutional quality from a theo- 
retical perspective; the literature from an empirical perspective remains in even shorter supply. Furthermore, the scarce research on the subject explores these relationships partially or indirectly. Only a specific aspect of institutional quality has been considered (Das and Di Renzo, 2010 and Poprawe, 2015 study corruption) or only a specific dimension of tourism has been examined (Lee, 2015 analyzes tourism competitiveness). Finally, Brau et al. (2011) and Altin et al. (2017) study the relationships between tourism and institutional quality in only an indirect way.

This paper strives to fill the gap left unfulfilled by the aforementioned studies. The main goal here is to determine whether there is a significant relationship between the specialization in tourism of a country and the quality of its institutions. If this is the case, then the objective becomes the determination of the sign of the relation and the underlying mechanisms that explain such a relation.

To achieve our goals, we use a sample of 92 countries over the period 1995-2014. Our econometric analysis shows that there is a significant and positive association between tourism specialization and institutional quality. Moreover, it indicates that this relationship is explained mainly through three of the four channels proposed: level of income $(40 \%)$, income inequality (25\%), and economic freedom (4\%).

This paper makes three principal contributions that may be useful for the improvement of tourism planning and the quality of institutions. On the one hand, it extends the literature on impacts of tourism on host societies by examining the relations between tourism and institutional quality. On the other hand, it extends the literature on institutional quality by analyzing its relation with sectoral specialization. Finally, to the best of our knowledge, this is the first study that evaluates the channels through which tourism affects institutional quality.

The rest of the paper is organized as follows. Section 2 introduces a review of the literature and the theoretical framework on which our model is based. Section 3 describes the data and variables. Section 4 offers the econometric model, the estimation approach, and discusses the results of the analysis concerning the relationship between tourism and quality of institutions. Finally, Section 5 provides concluding remarks.

\section{LITERATURE REVIEW AND THEORETICAL ARGUMENTS}

The relationship between tourism and quality of the institutions of the societies where it is developed has, hitherto, been little studied. In addition, this limited research explores such relationships only partially or indirectly (Das and Di Renzo, 2010; Brau et al., 2011; Lee, 2015; Poprawe, 2015). The specific links that can be established between the two issues remain uncertain.

Lee (2015) employs a cross-country regression analysis of 117 countries and finds that quality of government is positively associated with international tourism competitiveness (Travel and Tourism Competitiveness Index). Furthermore, this study concluded that the positive effect of quality of government is independent from the effect of democracy.

Moreover, Das and Di Renzo (2010) and Poprawe (2015) focus on the analysis of the relationship between tourism and on one specific dimension of institutional quality: that of corruption. Das and Di Renzo (2010) provide evidence for 119 countries that a reduction 
in corruption causes a positive impact on the level of tourism competitiveness (Travel and Tourism Competitiveness Index). They also find that "developing nations enjoy a larger marginal gain in tourism competitiveness compared to developed countries as a result of a reduction in corruption levels" (Das and Di Renzo 2010: 489). Poprawe (2015) tests the hypothesis that corruption has a negative effect on tourism, using a panel data set of over 100 countries and 16 years.

Brau et al. (2011) evaluate whether the positive role of the tourism sector for growth varies depending on the quality of institutions, and employ a large sample of countries covering the period 1980-2007. They conclude the positive effect of tourism development on aggregate growth acts independently of a country's institutional quality.

The above studies constitute just the beginning of research in this area. It is therefore necessary further study into the relationship between tourism and institutional quality in order to understand the channels through which tourism can affect this quality.

For a better understanding of this relation, we will distinguish between the total effect and its decomposition into direct and indirect effects.

\subsection{Total effect}

The total effect of tourism on institutional quality is derived from the specific characteristics of this sector: (a) experience good, (b) importance of public services, (c) importance of image, (d) existence of market failures.

The tourism product is considered as an experience good (Hunt, 1975). Tourists often have little or no first-hand knowledge of the destination before travelling, and hence have had no opportunity to test the product before purchasing. In these cases, the image becomes a key factor in choosing a destination (Oh et al., 2007; Yuan and Wu, 2008).

In this regard, there are studies that have shown that both corruption and political instability tarnish a country's image or destination brand (Das and Di Renzo, 2010; Poprawe, 2015). Corruption, in addition to damaging the image, usually incurs higher costs for both tourists and investors, thereby representing a loss of competitiveness for the destination (Dwyer and Kim, 2003; Enright and Newton, 2004; 2005)

On the other hand, the image perceived by tourists is closely linked with both quantity and quality of public services they have received at the destination: cleanliness, air and noise pollution, traffic congestion, security and safety, overcrowding, state of infrastructure, and the preservation of historical and natural heritage, among others (Beerli and Martin, 2004). These services, in turn, are directly related to the quality and flexibility of the existing institutions in host communities, since it is these institutions which must ultimately provide the services.

The image of a destination exhibits most of the features of a public good. Therefore, public sector intervention is important in achieving an image consistent with the objectives of the tourism sector. Furthermore, quality institutions are needed in order to coordinate the interests of the various stakeholders in tourism in order to present a coherent image (Higgins-Desbiolles, 2006).

In the latter sense, as suggested by Sinclair (1998), tourism presents other market failures, which explains why it is especially important to have quality institutions to over- 
come these failures and to ensure the success of the sector. Failures of the tourist market include the noticeable concentration in certain segments (tour operators, air transport, etc.), problems of asymmetric information, and both positive and negative externalities (tourism directly affects the lives of host communities and can cause significant economic, social and environmental impacts). In addition, tourism could give rise to problems in the distribution of income (from the point of view of temporal and spatial and personnel distribution).

Given the above features, the development of tourism should not be solely left to the mercy of market forces if its benefits are to be secured (OECD, 1991; Hall and Page, 2006). As early as 1974, the International Union of Tourism Organizations identified five areas of public sector involvement in tourism: coordination, planning, legislation, regulation, and entrepreneur stimulation (IUTO, 1974).

For all these reasons, countries seeking a competitive specialization in sustainable tourism over time will have greater incentives to improve their institutional quality by enhancing the quality of their bureaucracy, controlling corruption, and ensuring a strong and impartial legal system (law and order).

In addition to those incentives through which tourism can generate positive impacts on institutional quality, there are forces acting in the opposite direction, particularly in certain specific tourism typologies. Nkyi and Hashimoto (2014) overview existing evidence in the literature about growing incidences of human rights abuses in the tourism industry. These include inhuman treatment of people (slavery, sexual exploitation, human trafficking, child exploitation for labour), labour rights violation, restrictions on the freedom of settlement and movement, unfair business competition between local small business entities and multi-national corporations, and environmental exploitation.

Building on the above considerations, we establish the first hypothesis of our work:

H1: There is a link between tourism specialization and the quality of institutions

Having found that there are theoretical arguments that justify the existence of links between tourism and institutional quality, we explore the main channels through which these associations may occur. In this respect, we decompose the total effect into direct and indirect effects. The indirect effects are those induced by various channels, whereby tourism exerts an impact on the channels and these in turn have an effect on the quality of institutions. The direct effect is defined in this paper as a residual, that is, the part of the total effect that cannot be explained with the channels.

\subsection{Indirect effects: channels}

Tourism can affect institutional quality by influencing its determinants. In this paper, we will consider channels to be the determinants of institutional quality in which there is clear evidence of their link with tourism.

There is a vast literature dedicated to the search for determinants of the quality of institutions. These can be classified into two main groups: stable determinants and changing determinants. The former covers historical (colonial and legal origin), geographical, cultural and ethnic factors (see Acemoglu et al. 2001; La Porta et al., 1999; Auer, 2013; Alesina and Giuliano, 2015; and Alesina and La Ferrara, 2005, respectively). In the latter, we find education, economic determinants, and political institutions. In order to select the channels, we 
have focused on the economic determinants given that they could be more closely related to tourism. Economic factors include level of income, openness, inequality in the distribution of income, market competition measured as economic freedom, and economic variables related to the government in the form of the tax system or government expenditure (for a review of changing determinants, see Alonso and Garcimartín, 2013; and Treisman, 2007). Among all these determinants, we have selected those that the literature links to tourism: level of income, income inequality, economic freedom, and international openness.

\section{Tourism and Level of Income}

The links between tourism and level of income have been widely studied by the scientific literature both from a theoretical and empirical perspective for decades (see Sinclair, 1998 and Pablo-Romero and Molina, 2013 for reviews of the literature). Despite using different methodologies, different samples, and obtaining different results, most of these studies aim to verify the tourist-led growth hypothesis.

Several studies focus on the estimation of income generation via the multiplier process using Input-Output Analysis, on Computable General Equilibrium models, and on Tourism Satellite Accounts (Fletcher and Archer, 1991; Dwyer et. al., 2004; Ivanov and Webster, 2007; Kadiyali and Kosová, 2013).

Other studies have examined the causal relationships between tourism and growth, as well as tourism potential to affect growth through various channels: exports, tax revenue, employment creation, investment, productive diversification, enhancing efficiency, and gains from economies of scale, among others. These studies use a range of econometric methodologies: time series, panel-data, and cross-sectional analyses (Brau et al., 2011; Lejarraga and Walkenhorst, 2013). Although their results differ, there is evidence of the existence of a clear relationship between tourism and economic growth (82 out of the 86 studies analyzed in Pablo-Romero and Molina, 2013, show a connection between the two issues). Furthermore, most conclude that specialization is relevant in tourism in order for it to affect growth; however, these studies also provide evidence of a decreasing marginal effect of tourism on economic growth over time.

\section{Tourism and Income Inequality}

The majority of the studies analyzing the relationship between tourism and income inequality have investigated from the point of view of spatial distribution.

The effects of tourism on personal income distribution have remained less studied by the academic literature. These studies generally use a Gini coefficient or a Lorenz curve and their results are mixed, although the strength and direction of links between tourism and income distribution seem to be very sensitive to the choice of country and remain context-specific.

Blake (2008), in his analysis of household income in East Africa, finds that tourismrelated industries provide substantially less income for poorer segments of the population than other export activities. Likewise et al. (2008) conclude from applied General Equili- 
brium Analysis that tourism development has adverse effects on income distribution in the Thai economy. Leatherman and Marcouller (1996, 1999), using Social Accounting Matrix, found that tourism development benefits especially upper- and lower-income categories in rural economies. The results of Wagner (1997) are in the same vein.

In contrast, Croes and Vanegas (2008) study the Nicaraguan economy and they provide evidence of the existence of a relation between tourism development and poverty reduction. In this vein, Casas Jurado et al. (2012) show the role of tourism in the eradication of poverty in Peru using a case study. Lee and Kang (1998) obtain similar results for South Korea; in general, tourism provokes a more evenly spread earnings distribution than do secondary and tertiary industries. These results are mainly due to the characteristics of tourism employment: it is of a labour-intensive nature; and it absorbs many unskilled and semi-skilled workers and female workers. Thus, the tourism employment is more likely to improve living standards for those of a lower income.

Finally, Marcouiller et al. (2004) offers contradictory evidence in a country-level model for the US lake states.

\section{Tourism and Economic Freedom}

Although the relationship between tourism and economic freedom has yet to be sufficiently studied, in general there seems to be a broad consensus in the literature that shows a positive and significant relationship between economic freedom and competitiveness of a tourist destination (Dwyer and Kim, 2003; Enright and Newton, 2004; 2005; Das and Di Renzo, 2010). Das and Di Renzo (2010: 481) conclude that "tourism tends to thrive in stable economic and business environments where institutions and policies are open, consistent and free, and where countries have greater levels of economic freedom".

Lejarraga and Walkenhorst (2013: 3) indicate that factors such as "the business environment, such as corporate tax rate, labor market regulations, and internet usage, as well as trade regulations, such as tariff and non-tariff measures, have the most pronounced impact on the formation of tourism linkages" with the general economy. These factors are all related with economic freedom.

\section{Tourism and International Openness}

In the same way as for economic freedom, most of the literature finds a positive relationship between international openness and tourism competitiveness. Thus, Gooroochurn and Sugiyarto (2005) found trade openness to be a significant determinant of tourism competitiveness. Ivanov and Webster (2013) show tourism is a function of globalization because the globalization process expedites the flow of travellers and investors across national borders. Likewise, the research of Lejarraga and Walkenhorst (2013) shows that an open trading environment encourages more linkages between tourism and the general economy than protectionist policies.

On the other hand, Poprawe (2015) and Lee (2015) introduced international openness as a control variable in its analysis of the relations between tourism and institutional quality (Poprawe, 2015 uses the Index for trade openness and Lee, 2015 the Index of 
globalization). Both studies conclude that there is a positive and significant relationship between tourism and openness.

In this respect, it is also important to note countries with greater tourist specialization are, in most cases, small economies, and consequently open countries (Brau et al., 2011).

Based on the above, we propose the following hypothesis:

H2: There is a link between tourism specialization and institutional quality through the following channels: level of income, income inequality, economic freedom and international openness

We propose the following theoretical model (Figure 1) in order to test our hypotheses.

\section{Figure 1 \\ CONCEPTUAL MODEL OF RELATIONSHIP BETWEEN TOURISM SPECIALIZATION AND INSTITUTIONAL QUALITY}

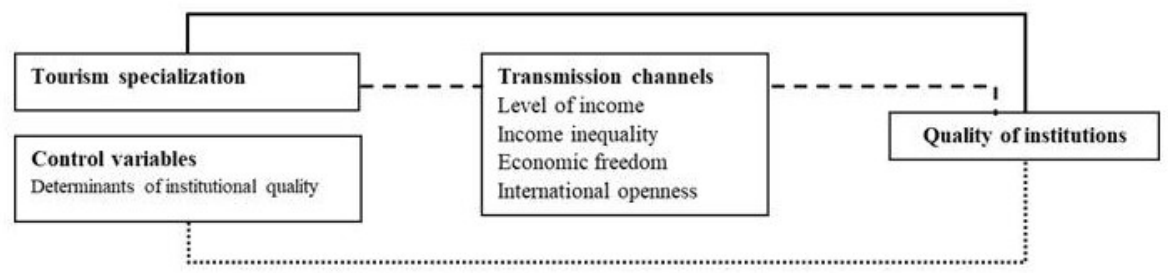

Note: The dashed lines represent the indirect effect and the solid line describes the direct effect.

In Section 3, a description is given of the variables included in the model, the index chosen for each of the variables, and the data source used. In Section 4, this model is specified in a set of equations which will be estimated using econometric techniques.

\section{DATA AND VARIABLES}

In order to test the existence of a relationship between specialization in tourism and institutional quality, data from of 92 countries from 1995 to 2014 is used. The total period has been divided into two sub-periods: 1995-2004 and 2005-2014.

Moreover, only those countries for which there is data available for all variables have been considered. Table A1 in Appendix 1 shows the countries included for each of the sub-periods.

A description and justification is then given of the variables used in our analysis and the index chosen for each of them.

\subsection{Quality of institutions}

The quality of institutions is our dependent variable. We have chosen the indicator available at the Dahlberg et al. (2016) constructed from the data produced by the firm Political Risk Services (PRS), based on evaluations by its network of experts and published in its International Country Risk Guide (ICRG). 
This indicator is the mean value of the ICRG indexes for Corruption, Law and Order, and Bureaucracy Quality. These variables are closely related to the aforementioned characteristics of tourism that explain its potential relationship with institutional quality

These indexes have been scaled from 0 to 10 , where higher values indicate higher quality of institutions. Dahlberg et al. (2016: 79) point out "that the index of Corruption is an assessment of corruption within the political system". It is concerned with actual or potential corruption in the form of excessive patronage, nepotism, job reservations, bribes, clientelism, and/or favouritism. It captures the likelihood that high government officials will demand special payments and the extent to which illegal payments are expected throughout government tiers. According to Dahlberg et al. (2016: 80), "the Law and Order index is twofold. The Law sub-component is an assessment of the strength and impartiality of the legal system, while the Order sub-component is an assessment of the popular observance of the law". Finally, these authors indicate that the Bureaucracy Quality index refers to the autonomy of bureaucracy from political pressure. A high value implies that changes in the government do not lead to drastic changes in policy or interruptions in government services. Low values are given to countries where a change in government tends to be traumatic in terms of policy formulation and day-to-day administrative functions.

The other two indexes that are most used in the literature are the Perception Corruption Index provided by Transparency International, and the Worldwide Governance Indicators of the World Bank. It is noteworthy that for our sample these indicators are highly correlated with the ICRG index. The correlation between the ICRG and the Perception Corruption Index is 0.909, and with the mean of the six indicators of the World Bank is 0.920.

\subsection{Tourism Specialization}

For the purposes of our work, an index is required that measures the impacts of tourism on economic activity. Since tourism is characterized by strong links with the rest of the economic activity (Dwyer et al., 2004; Ivanov and Webster, 2007; Kadiyali and Kosová, 2013), not only do we want to consider direct impacts, but also both indirect and induced effects.

Tourism Satellite Accounts (TSAs) are the main primary source for obtaining this data, and they provide full information about the impacts in terms of both income and employment. Currently, not all countries draw up their own TSAs. For more than 25 years, the World Travel and Tourism Council (WTTC) and Oxford Economics have striven to fill this gap by carrying out annual economic impact research for a large sample of countries (WTTC, 2016). Their estimates are consistent with definitions specified in the UN Statistics Division-approved Tourism Satellite Account methodology (WTO, 2010) and they include data of total impacts (direct, indirect and induced). Currently, the WTTC can therefore be considered the most comprehensive available source of consistent crosscountry data on tourism linkages.

Hence, in our work, to measure the tourism specialization, we use the total contribution of tourism employment offered by World Travel and Tourism Council and Oxford Economics: the number of jobs directly generated in the travel and tourism sector, plus 
indirect and induced effects measured as a percentage of the total employment contribution to the economy.

We have chosen the contribution of employment since tourism is a very labour-intensive economic activity and, therefore, a major part of its effects on income distribution are produced in this way. As Lee and Kang (1998) state, tourism is a source of employment for discriminated groups in the labour market: it offers opportunities for both low-skilled workers and women and enables workers to be transferred from the informal to the formal sector.

\subsection{Control variables}

As control variables, we have chosen a group of determinants of the quality of institutions, although economic factors have been excluded since they are included as channels through which tourism works on quality of institutions. The selection of the variables has been made depending on the availability of the data and the robustness of the results found in the literature. According to the classification in Section 2.2, we have chosen those stable and unstable elements that are well documented in the literature as determinants of quality of institutions. From the stable factors, the legal origin and the ethnical fractionalization have been selected, while from the unstable factors, we have chosen education, democracy and freedom of press.

\section{Index of Ethnic Fractionalization}

Since Huntington (1968) stated the negative impact of a fractionalized society on the quality of government, a growing literature has striven to show a negative relation between fractionalization and quality of institutions (see Alesina and Ferrara (2005) for a review of the literature).

The index of ethnolinguistic fractionalization measures the probability that two randomly selected people from a given country will not belong to the same ethnolinguistic group (Alesina et al., 2003: 158-159).

The most common index used in the literature (often referred to as ELF) was calculated by Taylor and Hudson (1972) and refers to 1960. Nevertheless, as Alesina et al. (2003: 156) point out, "these data rely largely on linguistic distinctions, which may obscure other aspect of ethnicity like racial origin, skin color, etc." Therefore these authors provide a new measure of ethnic fragmentation and construct an index based strictly on language and another index based strictly on religion. While the ELF index is provided for 112 countries, the ethnic, religion and language fractionalization indexes constructed by Alesina et al. (2003) are available for 180,198 and 185 countries, respectively. Furthermore, their ethnicity data refers to a period between 1983 and 2001 depending on the country, and the language and religion data to 2001. These characteristics have led us to select the fractionalization indexes in Alesina et al. (2003). In our sample, the correlation between the index of quality of institutions and the fractionalization indexes are -0.54 , for the ethnic index, -0.34 for the language index, and 0.11 for the religion index. As the ethnic index shows the highest level of autocorrelation, we have decided to introduce only this index into the model.

Legal Origin 
In a seminal paper, La Porta et al. (1999) show a systematic relation between legal origin and corruption. They identify five possible legal origins: the Common Law (British origin system), German commercial code, Scandinavian commercial law, the French commercial code (Civil law), and Socialist/communist law. It is argued that the Common Law, and, to a lesser extent German or Scandinavian systems, are based on a greater recognition of economic freedom and property rights, which limits state intervention in the economy. By contrast, the Civil Law and even more the Socialist/communist system were designed to determine the state's ability to organize economic and social life, leading to a weaker recognition of property rights and individual freedom. Accordingly, La Porta et al. (1999) show that countries whose legal system is based on the French legal origin exhibit greater corruption levels than countries with British and Nordic legal traditions. In our sample, there are 30 countries with legal origin in the English common law, 46 countries in the French tradition, 10 countries in the socialist tradition, 1 country in the German and 5 countries in the Scandinavian tradition (see Table A2 in Appendix 2). Therefore, we have included a dummy variable for English legal origin, a dummy variable for the French legal origin, and the excluded dummy variable includes countries with Socialist, German and Scandinavian legal traditions.

\section{Education and Democracy}

Alesina and Perotti (1996), Evans and Rauch (2000), Glaeser and Sacks (2006), and Alonso and Garcimartín (2013) find that education is positively related to quality of institutions. A more educated population demands institutions to be more transparent and efficient, is qualified to build these institutions, and is more sensitive to corruption problems. In this sense, Melgar et al. (2010: 125) found that "people who have completed, at least, secondary education are more likely to perceive a lower level of corruption. (...) More educated people have more information about the current level of corruption and better capabilities to process the information". Following this result, we measure education with the average years of secondary education completed among adult people (aged 25 and over). The data is taken from the Barro and Lee (2013) dataset.

Moreover, Fortunato and Panizza (2015) show that the marginal effect of education on the quality of institutions is significant in democratic countries, but it is not significant in non-democratic countries. This indicates that democracy channels the effects of a better education towards an improvement in the performance of the institutions. Based on this finding, we use the interaction between education and democracy as a control variable.

Democracy is measured by an average of the Polity and Freedom House indexes of democracy and ranges between 0 and 10, where higher values are associated with higher levels of democracy.

\section{Freedom of the Press}

Adsera et al. (2003), Brunetti and Weder (2003), and Treisman (2007) find that freedom of the press helps fight against corruption, thereby contributing to the improvement in quality of institutions. We have measured this variable with an index provided by Freedom 
House (available at Dahlberg et al., 2016) that reflects the political pressures and controls on media content. According to Dahlberg et al. (2016: 67), this index examines "the editorial independence of both state-owned and privately owned media; access to information and sources; official censorship and self-censorship; the vibrancy of the media; the ability of both foreign and local reporters to cover the news freely and without harassment; and the intimidation of journalists by the state or other actors, including arbitrary detention and imprisonment, violent assaults, and other threats." The index varies from 0 to 40 where 0 indicates the most freedom.

\subsection{Transmission channels}

\section{Level of Income}

While it is true that the debate over the direction of the causality between institutions and growth will remain as long as macroeconomists exist, there seems to be a consensus in the literature concerning the association between lower corruption and higher economic development (see Treisman, 2007). In our paper, we will deem the level of income as a determinant of the quality of institutions, considering, as Alonso and Garcimartín (2013: 210) point out, that a higher level of development provides the resources required to achieve better institutions and it entails an increase in the demand for quality institutions. Thus, we introduce the GDP per capita in PPP (purchasing power parity) in constant 2011 international dollars, as taken from the World Bank.

\section{Income Inequality}

Inequality in income distribution can be considered as an economic measure of the fragmentation of a society and, therefore, it has the same expected effect on the quality of institutions. The higher the fragmentation, the lower the quality of institutions: this arises because the groups in power use the institutions for their own interests instead of seeking the common good. Moreover, income inequality leads to social conflicts and political instability, which favour corruption, rent-seeking activities and, therefore, low-quality institutions. Alesina and Perotti (1996), Easterly (2001) and Alonso and Garcimarti (2013), among others, find evidence of this relationship.

As measures of inequality, we have chosen the Gini index (GINI) and the income share held by the lowest $20 \%$ of the population (L20), available at the World Bank. The Gini index ranges from 0 , indicating perfect equality, to 100 , indicating total inequality. Therefore, an increase in this index indicates a greater concentration of income. However, an increase in L20 indicates a higher percentage of income for the poorest section (in our estimates, the signs of the coefficients of these indices are expected to be opposite). Thus, although both indicators are measures of income distribution, their meanings are not exactly the same. L20 can complete the information offered by the Gini index on approaching poverty reduction. 


\section{Economic Freedom}

The positive relation between economic freedom and quality of institutions is widely supported by the literature (see Faria et al., 2012 and the references therein). Nevertheless, the concept of economic freedom as described in the various papers is not exactly the same.

As Faria et al. (2012: 513-514) point out, economic freedom is related to the degree of protection of private property. This freedom is "enhanced by lower trade barriers, absence of price and foreign exchange controls, simplified taxation and regulation, rule of law, protection of property rights and sound money among others." (Faria et al., 2012: 515). Taking all this into account the economic freedom index provided by the Heritage Foundation, and available at Dahlberg et al. (2016), is considered to cover most of these issues. This index ranges from 0 to 100 (the maximum economic freedom). According to Dahlberg et al. (2016: 74-75), the components of this index are: Business freedom, Trade freedom, Fiscal freedom, Freedom from Government, Monetary freedom, Investment freedom, Financial freedom, Property rights, Freedom from corruption, and labour freedom.

\section{International Openness}

International openness could improve institutional quality given that it encourages a more competitive environment that prevents rent-seeking activities and requires the good functioning of the numerous legal and bureaucratic procedures. Nevertheless, the results on this issue are mixed. Ades and Di Tella (1999), and Leite and Weidmann (1999) support this link, while Treisman (2000) and Brunetti and Weder (2003) find no relation between the two variables. Rigobon and Rodrik (2004) and Islam and Montenegro (2002) find ambiguous results depending on the institutional quality variables used.

Despite this lack of clear support of the empirical evidence, we have decided to include international openness in our model since it could constitute a channel through which tourism affects the quality of institutions. As is usual in the literature, we have taken the sum of imports plus exports of goods and services as a percentage of the GDP. This data was extracted from the World Bank.

Table 1 provides a summary of all the variables included in the model, the index chosen for each of them, their acronyms, and the data source used. The descriptive statistic for the variables is summarized in Appendix 3 (Table A3). 
Table 1

DATA DESCRIPTION AND SOURCES

\begin{tabular}{|c|c|c|c|}
\hline Name & Variable & Index/Description & Source \\
\hline ICRG & $\begin{array}{l}\text { Quality of } \\
\text { institutions }\end{array}$ & $\begin{array}{l}I C R G \text { : measure of quality of institutions; } \\
\text { the mean of three indicators of } \\
\text { 'corruption', 'law and order' and } \\
\text { 'bureaucracy quality' }\end{array}$ & $\begin{array}{l}\text { Political Risk Services } \\
\text { Group }\end{array}$ \\
\hline TS & $\begin{array}{l}\text { Tourism } \\
\text { specialization }\end{array}$ & $\begin{array}{l}\text { Total contribution of tourism } \\
\text { employment: number of jobs generated } \\
\text { directly in the travel and tourism } \\
\text { sector, plus indirect and induced effects } \\
\text { measured as a percentage of the total } \\
\text { employment contribution to the economy }\end{array}$ & $\begin{array}{l}\text { World Travel and } \\
\text { Tourism Council and } \\
\text { Oxford Economics }\end{array}$ \\
\hline FRAC & $\begin{array}{l}\text { Ethnic } \\
\text { fractionalization }\end{array}$ & $\begin{array}{l}\text { Index of ethnic fractionalization: the } \\
\text { probability that two randomly selected } \\
\text { people from a given country will not } \\
\text { belong to the same ethnolinguistic group }\end{array}$ & Alesina et al. (2003) \\
\hline $\begin{array}{l}\text { COMMON } \\
\text { LAW } \\
\text { FRENCH } \\
\text { LAW }\end{array}$ & Legal origin & $\begin{array}{l}\text { Five possible legal origins: the Common } \\
\text { law (British origin system), German } \\
\text { commercial code, Scandinavian } \\
\text { commercial law, the French commercial } \\
\text { code (civil law), and Socialist/communist } \\
\text { law }\end{array}$ & La Porta et al. (1999) \\
\hline EDUC & Education & $\begin{array}{l}\text { Average years of secondary education } \\
\text { completed among adult people (aged } 25 \\
\text { and over) }\end{array}$ & $\begin{array}{l}\text { Barro and Lee (2013) } \\
\text { dataset }\end{array}$ \\
\hline DEMOC & Democracy & $\begin{array}{l}\text { Average of the Polity and Freedom } \\
\text { House indices of democracy }\end{array}$ & Freedom House \\
\hline FP & $\begin{array}{l}\text { Freedom of the } \\
\text { press }\end{array}$ & $\begin{array}{l}\text { Index Freedom of the press: reflects the } \\
\text { political pressures and controls on media } \\
\text { content }\end{array}$ & Freedom House \\
\hline GDP & Level of income & $\begin{array}{l}\text { Log of GDP per capita in PPP in constant } \\
2011 \text { international dollars }\end{array}$ & $\begin{array}{l}\text { World Development } \\
\text { Indicator (World Bank) }\end{array}$ \\
\hline GINI & Income inequality & - Gini index & World Development \\
\hline L20 & & $\begin{array}{l}\text { - Income share held by lowest } 20 \% \text { of the } \\
\text { population }\end{array}$ & Indicator (World Bank) \\
\hline $\mathrm{EF}$ & Economic freedom & $\begin{array}{l}\text { Economic freedom index: This includes } \\
10 \text { components (Business freedom, } \\
\text { Trade freedom, Fiscal freedom, Freedom } \\
\text { from government, Monetary freedom, } \\
\text { Investment freedom Financial freedom, } \\
\text { Property rights, Freedom from corruption, } \\
\text { and labour freedom) }\end{array}$ & Heritage Foundation \\
\hline OPEN & $\begin{array}{l}\text { International } \\
\text { openness }\end{array}$ & $\begin{array}{l}\text { Sum of imports plus exports of goods } \\
\text { and services in percentage of the GDP }\end{array}$ & $\begin{array}{l}\text { World Development } \\
\text { Indicator (World Bank) }\end{array}$ \\
\hline
\end{tabular}




\section{METHODOLOGY AND RESULTS}

In this section, the results for the total period 1995-2014 are presented. The results for each sub-period are detailed separately in Appendix 4.

As a first step, we obtain the total effect $(\theta)$ of tourism on quality of institutions by estimation using the OLS equation (1), where the transmission channels have been excluded.

$$
I C R G_{i, t}=\text { constant }+\vartheta T S_{i, t}+\gamma X_{i, t}+\epsilon_{i, t}
$$

$X_{i, t}$ is the matrix of the control variables described in Section 3. Results in Table 2, column E(1) show that the total effect is positive and significant. If we compare the two periods it can be seen that in period 1 the total effect is slightly higher than in period 2 (Appendix 4). These results support our first hypothesis (see Section 2.1) regarding the existence of a link between tourism specialization and the quality of institutions.

In order to test our second hypothesis (see Section 2.2), we decomposed the total effect ( $\theta$ ) into a direct effect of tourism on quality of institutions (denoted as $\alpha$ ) and an indirect effect through the different channels, selected from the literature review and described in Section 3. This decomposition can be expressed as in (2):

$$
\vartheta=\alpha+\sum_{j} \frac{\partial I C R G}{\partial C H^{j}} \frac{\partial C H^{j}}{\partial T S}
$$

where $\frac{\partial I C R G}{\partial C H^{j}} \frac{\partial C H^{j}}{\partial T S}$ is the indirect effect of tourism on ICRG through each selected channel $j\left(\mathrm{CH}^{\mathrm{j}}\right)$, that is, international openness, level of income, income inequality, and economic freedom.

As a previous condition to estimate both the direct and indirect effect, we have to test that the channels selected are determinants of quality of institutions. To this end, we include each plausible channel $j$ in equation (1):

$$
I C R G_{i, t}=\text { constant }+\alpha T S_{i, t}+\beta^{j} C H_{i, t}^{j}+\gamma X_{i, t}+\omega_{i, t}
$$

and we take into account the effects of tourism on ICRG through each channel by applying equation (4).

$$
C H_{i, t}^{j}=\text { constant }+\delta^{j} T S_{i, t}+\rho X_{i, t}+u_{i, t}
$$

where $j$ is openness, GDP, income inequality, or economic freedom. We apply SURE to estimate the system with the two above equations (3 and 4). Since, in this step, the relevant parameter is $\beta j$, we present only the results of the estimation of (3) for each channel $j$. These appear in Table 2, columns E2 to E6. OPEN is neither significant for the total period nor for the first period. For the second period $O P E N$ is significant only at a $10 \%$ level of significance (see Table A4.1b in Appendix 4). Thus, it is excluded from the analysis, and the channels selected are therefore GDP, income inequality (IQ) measured by Gini or L20, and EF. It is interesting to note that, as expected, when transmission variables are included, the magnitude and the level of significance of the direct effect of tourism on ICRG, estimated by $\alpha$, decrease. This can be interpreted as an indirect support concerning the role of the transmission channels. 
Table 2

EFFECT OF TOURISM ON QUALITY OF INSTITUTIONS (1995-2014)

\begin{tabular}{|c|c|c|c|c|c|c|c|c|}
\hline \multicolumn{9}{|c|}{ Dependent Variable: Quality of Institutions (ICRG) } \\
\hline & $\mathrm{E}(1)$ & $\mathrm{E}(2)$ & $\mathrm{E}(3)$ & $\mathrm{E}(4)$ & $\mathrm{E}(5)$ & $\mathrm{E}(6)$ & $\mathrm{E}(7)$ & $\mathrm{E}(8)$ \\
\hline TS & $\begin{array}{l}0.192^{* * *} \\
(3.529)\end{array}$ & $\begin{array}{l}0.181^{* * *} \\
(3.312)\end{array}$ & $\begin{array}{l}0.090^{*} \\
(1.786)\end{array}$ & $\begin{array}{l}0.138^{* * *} \\
(2.622)\end{array}$ & $\begin{array}{l}0.131^{* * *} \\
(2.507)\end{array}$ & $\begin{array}{l}0.185^{* * *} \\
(3.554)\end{array}$ & $\begin{array}{l}0.045 \\
(0.959)\end{array}$ & $\begin{array}{l}0.036 \\
(0.769)\end{array}$ \\
\hline
\end{tabular}

Channels:

\begin{tabular}{|c|c|c|c|c|c|c|}
\hline OPEN & $\begin{array}{l}0.002 \\
(1.121)\end{array}$ & & & & & \\
\hline GDP & $\begin{array}{l}0.897^{* * *} \\
(6.198)\end{array}$ & & & & $\begin{array}{l}0.725^{* * *} \\
(5.152)\end{array}$ & $\begin{array}{l}0.759^{* * *} \\
(5.502)\end{array}$ \\
\hline GINI & & $\begin{array}{l}-0.048^{* * *} \\
(-4.114)\end{array}$ & & & $\begin{array}{l}-0.052^{* * *} \\
(-4.994)\end{array}$ & \\
\hline L20 & & & $\begin{array}{l}0.232^{* * *} \\
(4.499)\end{array}$ & & & $\begin{array}{l}0.249^{* * *} \\
(5.502)\end{array}$ \\
\hline EF & & & & $\begin{array}{l}0.054^{* * *} \\
(3.443)\end{array}$ & $\begin{array}{l}0.048^{* * *} \\
(3.263)\end{array}$ & $\begin{array}{l}0.044^{* * *} \\
(5.532)\end{array}$ \\
\hline
\end{tabular}

Control variables:

\begin{tabular}{|c|c|c|c|c|c|c|c|c|}
\hline EDUC*DEMOC & $\begin{array}{l}0.065^{* * *} \\
(7.083)\end{array}$ & $\begin{array}{l}0.062^{* * *} \\
(6.704)\end{array}$ & $\begin{array}{l}0.009 \\
(0.782)\end{array}$ & $\begin{array}{l}0.059^{* * *} \\
(6.631)\end{array}$ & $\begin{array}{l}0.063^{* * *} \\
(7.183)\end{array}$ & $\begin{array}{l}0.049^{* * *} \\
(4.924)\end{array}$ & $\begin{array}{l}0.0008 \\
(0.071)\end{array}$ & $\begin{array}{l}0.0036 \\
(0.329)\end{array}$ \\
\hline FRAC & $\begin{array}{l}-0.807 * \\
(-1.756)\end{array}$ & $\begin{array}{l}-0.896^{* *} \\
(1.911)\end{array}$ & $\begin{array}{l}-0.283 \\
(-0.689)\end{array}$ & $\begin{array}{l}-0.844^{* *} \\
(-1.983)\end{array}$ & $\begin{array}{l}-0.871^{* *} \\
(-2.064)\end{array}$ & $\begin{array}{l}-0.629 \\
(-1.446)\end{array}$ & $\begin{array}{l}-0.249 \\
(0.663)\end{array}$ & $\begin{array}{l}-0.260 \\
(-0.702)\end{array}$ \\
\hline $\begin{array}{l}\text { COMMON } \\
\text { LAW }\end{array}$ & $\begin{array}{l}0.048 \\
(0.135)\end{array}$ & $\begin{array}{l}0.099 \\
(0.274)\end{array}$ & $\begin{array}{l}0.118 \\
(0.667)\end{array}$ & $\begin{array}{l}0.485 \\
(1.562)\end{array}$ & $\begin{array}{l}0.499^{*} \\
(1.632)\end{array}$ & $\begin{array}{l}-0.291 \\
(-0.932)\end{array}$ & $\begin{array}{l}0.269 \\
(0.967)\end{array}$ & $\begin{array}{l}0.305 \\
(1.113)\end{array}$ \\
\hline $\begin{array}{l}\text { FRENCH } \\
\text { LAW }\end{array}$ & $\begin{array}{l}-0.465 \\
(-1.296)\end{array}$ & $\begin{array}{l}-0.447 \\
(-1.250)\end{array}$ & $\begin{array}{l}-0.796^{* * *} \\
(-3.067)\end{array}$ & $\begin{array}{l}0.054 \\
(0.182)\end{array}$ & $\begin{array}{l}0.163 \\
(0.544)\end{array}$ & $\begin{array}{l}-0.731^{* * *} \\
(-2.578)\end{array}$ & $\begin{array}{l}-0.426^{*} \\
(-1.615)\end{array}$ & $\begin{array}{l}-0.309 \\
(-1.165)\end{array}$ \\
\hline FP & $\begin{array}{l}-0.059^{* * *} \\
(-3.742)\end{array}$ & $\begin{array}{l}-0.059^{* * *} \\
(-3.652)\end{array}$ & $\begin{array}{l}-0.070^{* * *} \\
(5.071)\end{array}$ & $\begin{array}{l}-0.054^{* * *} \\
(-3.733)\end{array}$ & $\begin{array}{l}-0.053^{* * *} \\
(-3.671)\end{array}$ & $\begin{array}{l}-0.041^{* * *} \\
(-2.654)\end{array}$ & $\begin{array}{l}-0.048^{* * *} \\
(-3.490)\end{array}$ & $\begin{array}{l}-0.048^{* * *} \\
(3.542)\end{array}$ \\
\hline Constant: & $\begin{array}{l}5.263^{* * *} \\
(9.446)\end{array}$ & $\begin{array}{l}5.160^{* * *} \\
(8.325)\end{array}$ & $\begin{array}{l}-1.297 \\
(-1.103)\end{array}$ & $\begin{array}{l}7.105^{* * *} \\
(10.333)\end{array}$ & $\begin{array}{l}3.581^{* * *} \\
(5.613)\end{array}$ & $\begin{array}{l}2.153^{* *} \\
(2.056)\end{array}$ & $\begin{array}{l}-0.814 \\
(0.665)\end{array}$ & $\begin{array}{l}-4.662^{* * *} \\
(-3.791)\end{array}$ \\
\hline N: observations & 159 & 158 & 156 & 159 & 159 & 159 & 156 & 156 \\
\hline $\mathrm{R}^{2}$ & 0.688 & 0.689 & 0.754 & 0.716 & 0.722 & 0.708 & 0.791 & 0.797 \\
\hline
\end{tabular}

Notes: ${ }^{* * *}, * * *$ denote that the coefficients are significant at $1 \%, 5 \%$, and $10 \%$ levels, respectively. The t-statistics are given within parentheses. Column E(1) shows OLS estimation of equation (1). Columns E(2) to E(6) present the SUR estimation of equation (3) for each channel, while considering the system of equations that is comprised of equations (3) and (4). Columns E(7) and E(8) show the SUR estimation of equation (5) in the system of equations (5) to (8), while considering the channels that are significant according to the results in $\mathrm{E}(2)$ to $\mathrm{E}(6)$. 
Once the three significant channels have been selected, we can calculate, on the one hand, the indirect effect of tourism on ICRG through each channel: $\frac{\partial I C R G}{\partial C H^{j}} \frac{\partial C H^{j}}{\partial T S}=\beta^{j} \delta^{j}$ where $\beta^{j}$ is the effect of each channel on ICRG and $\delta^{j}$ is the effect of tourism on each channel $j$.

On the other hand, the direct effect of tourism $(\alpha)$ can also be obtained, once the channels are taken into account. If we use the results of the system of equations (3) and (4), then the direct effect of tourism will be magnified, given that we have detracted the effect of one channel only. Therefore, it is more appropriate to analyze all channels simultaneously. This leads us to estimate the following system with four equations:

$$
\begin{aligned}
& I C R G_{i, t}=\text { constant }+\alpha T S_{i, t}+\beta C H_{i, t}+\gamma X_{i, t}+\omega_{i, t} \\
& C H_{i, t}^{G D P}=\text { constant }+\delta^{G D P} T S_{i, t}+\rho_{G D P} X_{i, t}+u_{i, t} \\
& C H_{i, t}^{I Q}=\text { constant }+\delta^{I Q} T S_{i, t}+\rho_{I Q} X_{i, t}+v_{i, t} \\
& C H_{i, t}^{E F}=\text { constant }+\delta^{E F} T S_{i, t}+\rho_{E F} X_{i, t}+z_{i, t}
\end{aligned}
$$

where $\mathrm{CH}$ is the matrix of the three channels considered and $\beta$ is the vector of the estimated effect of the three channels on ICRG. The estimation of (5) appears in Table 2, columns $\mathrm{E}(7)$ and $\mathrm{E}(8)$. The parameters $\rho_{G D P}, \rho_{I Q}$ and $\rho_{E F}$ are the vectors of the estimated coefficients of the control variables for each channel. The estimation of $\delta^{G D P}, \delta^{E F}, \rho_{G D P}$, and $\rho_{E F}$ in equations (6) and (8) are very similar regardless of whether the Gini index or L20 is considered in equation (7); in fact, they only change from the third decimal place. It is worth bearing in mind that neither do the estimations of the channels differ from those obtained in the system with (3) and (4). The results in Table 3 for equations (6) and (8) are for the equation system considering the Gini index in equation (7). With these estimations, we can calculate expression (2).

Table 3

EFFECT OF TOURISM ON CHANNELS (1995-2014)

\begin{tabular}{lllll}
\hline \multicolumn{1}{l}{ Dependent variable: Channels } & & & \\
\hline & GDP & GINI & L20 & EF \\
\hline TS & $0.105^{* * *}$ & $-0.824^{* * *}$ & $0.189^{* * * *}$ & 0.147 \\
& $(4.341)$ & $(-2.845)$ & $(2.824)$ & $(0.652)$ \\
EDUC*DEMOC & $0.064^{* * * *}$ & $-0.132^{* *}$ & 0.012 & $0.287^{* * *}$ \\
& $(13.806)$ & $(2.356)$ & $(0.953)$ & $(6.589)$ \\
FRAC & & & & \\
& $-0.625^{* * *}$ & -1.474 & 0.412 & $-3.180^{*}$ \\
COMMON LAW & 0.007 & $(-0.580)$ & $(0.702)$ & $(-1.608)$ \\
& $(0.053)$ & $9.370^{* * *}$ & $-2.089^{* * * *}$ & $5.555^{* * *}$ \\
FRENCH LAW & $0.342^{* *}$ & $(5.325)$ & $(-5.137)$ & $(4.051)$ \\
& $(2.494)$ & $10.297^{* * * *}$ & $-2.633^{* * * *}$ & $4.445^{* * *}$ \\
& & $(6.304)$ & $(6.975)$ & $(3.494)$ \\
\hline
\end{tabular}




\begin{tabular}{lllll}
\hline \multicolumn{2}{l}{ Dependent variable: Channels } & & & \\
\hline & GDP & GINI & L20 & EF \\
\hline FP & 0.008 & 0.076 & -0.017 & $-0.322^{* * * *}$ \\
& $(1.073)$ & $(0.837)$ & $(0.817)$ & $(-4.523)$ \\
Constant & $7.275^{* * *}$ & $37.953^{* * *}$ & $7.190^{* * *}$ & $57.364^{* * * *}$ \\
& $(26.379)$ & $(11.543)$ & $(9.462)$ & $(22.400)$ \\
\hline N: observations & 176 & 179 & 179 & 179 \\
$\mathrm{R}^{2}$ & 0.753 & 0.345 & 0.299 & 0.593 \\
\hline
\end{tabular}

Notes: ${ }^{* * * * * *}$, denote that the coefficients are significant at $1 \%, 5 \%$, and $10 \%$ levels, respectively. The t-statistics are given within parentheses. Columns GDP, GINI and EF present the SUR estimation of equations (6), (7) and (8), respectively, in the system of equations (5) to (8). Column L20 shows the SUR estimation of equation (7) in the system of equations comprised of equations (5) to (8).

Table 3 presents the results for the estimation of equations (6) to (8). These results show that the relation of tourism with each channel presents the expected sign and are consistent with those found in the previous literature. Higher specialization in tourism leads to a higher GDP, as found in the review of the literature made by Pablo-Romero and Molina (2013), and leads to higher economic freedom in line with the conclusions in Das and Di Renzo (2010), Dwyer and Kim (2003), and Enright and Newton (2004, 2005). Moreover, there is a positive association between L20 and tourism and a negative association with the Gini index. Similar results appear in Croes and Vanegas (2008), Casas Jurado et al. (2012) and Lee and Kang (1998), but our findings contradict those in Leatherman and Marcouller (1996; 1999), Wagner (1997), Blake (2008), and Wattanakuljarus and Coxhead (2008).

From these results, we summarize in Table 4 the estimation of direct and indirect effects of tourism on the quality of institutions. The estimations for each sub-period appear in Appendix 4, Tables A4.3a and 3b. As can be seen, for the total period, more than 40\% of the effect of tourism on ICRG is explained by the GDP. This percentage is lower in the first period and higher in the second period. With respect to income inequality, GDP explains approximately $25 \%$ of the total effect of tourism on the quality of institutions. Comparing the two sub-periods, the percentage explained both by Gini and L20 is slightly higher in the second period. Furthermore, results for Gini are slightly lower than those for L20 both in the total period and in the two sub-periods. As far as economic freedom is concerned, this explains around 5\%, although there are major differences between periods. For the first period, economic freedom is hardly relevant (around 2\%), while for the second period it is more relevant (around 15\%). Nevertheless, $\delta^{E F}$ is not significant and therefore these results must be viewed cautiously. The direct effect of tourism, or at least the effects that cannot be explained by these channels, stand at around $20 \%$, higher in the first period and lower in the second, due to the differences in the relevance of the economic freedom.

Our results are compatible with those obtained by Lee (2015) who found a positive association between the quality of institutions and tourism competitiveness. In the same vein, Das and Di Renzo (2010) and Poprawe (2015) found a negative impact of corruption on tourism. 


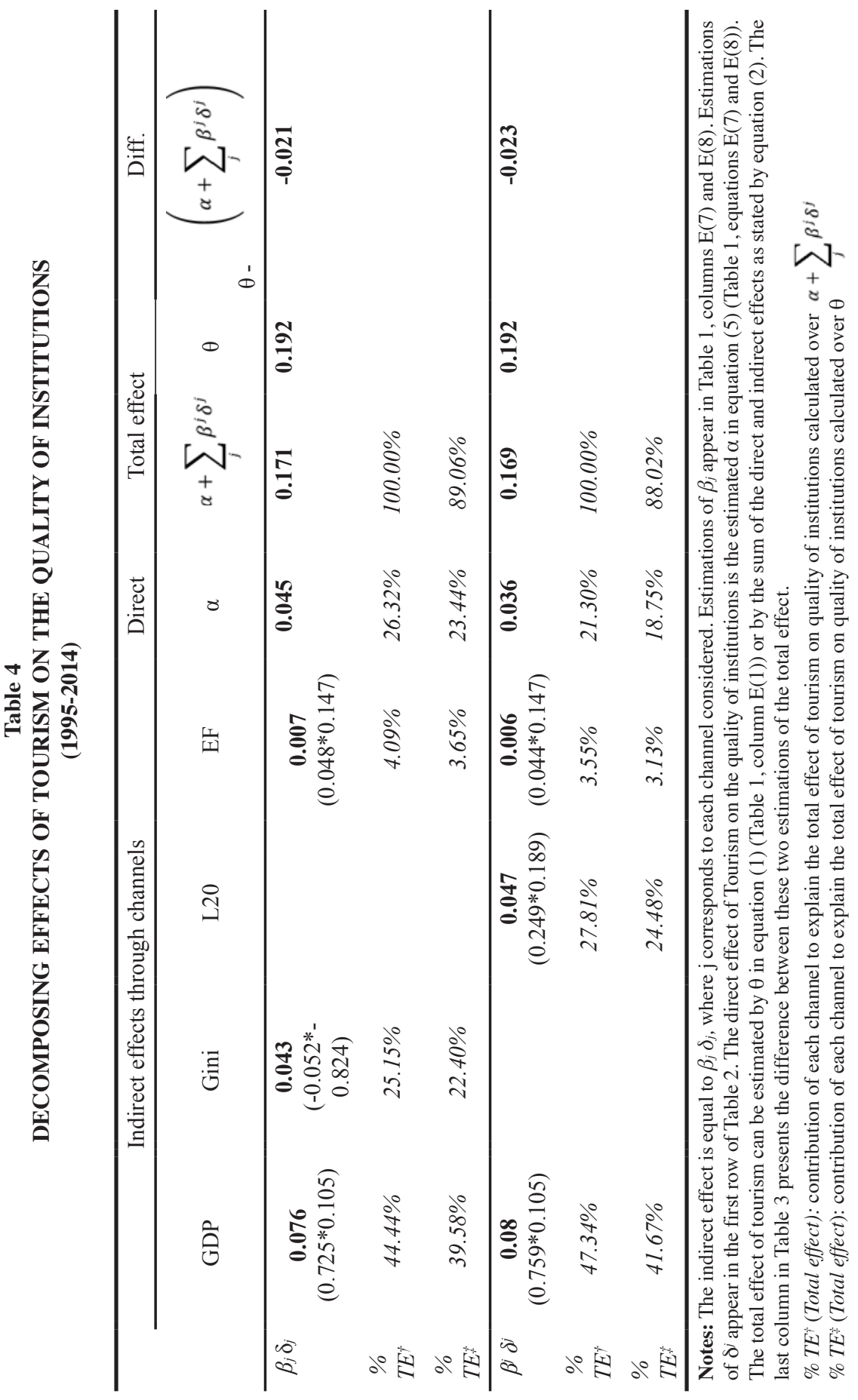


Finally, it is also worth noting that, in all regressions in Table 2, the estimates for control variables, when significant, show the expected sign and are consistent with the existing literature on the determinants of the quality of institutions.

\section{CONCLUSIONS}

This study has introduced a new perspective on the impacts of tourism on host communities by analyzing the links between the tourism specialization of a country and its institutional quality. Building on the literature review, we have proposed hypotheses and the theoretical model. An econometric analysis has been carried out using panel data on 92 countries from 1995 to 2014 . The empirical analysis has enabled us to find a positive and significant association between tourism specialization and institutional quality.

After having confirmed the links between tourism and institutional quality, we explored the transmission channels through which those links could occur. This paper, to the best of our knowledge, is the first to study these transmission channels. Initially, we have chosen, from among the determinants of institutional quality, those with a clearer connection with tourism: level of income, income inequality, economic freedom and international openness. Our empirical analysis found international openness to be non-significant and it was hence excluded from the analysis. This research leads to the conclusion that the relationship between tourism and institutional quality is mainly produced through three channels. The first channel is the income level that explains around the $40 \%$ of this relation. In fact, tourist activity fosters the income of the economy where it develops, which has a positive effect on the quality of institutions. The second channel is the income inequality. In this case, as tourism is of a labour-intensive nature, it absorbs many unskilled and semi-skilled workers and female workers. In this sense, the tourism employment is more likely to reduce income inequality because it improves living standards for those of a lower income. Our results show that this channel explains approximately the $25 \%$ of the total effect of tourism on the quality of institutions. Finally, the contribution of economic freedom is significant but residual (4\%).

These findings have potentially important implications for economic policy. On the one hand, these results broaden the knowledge of the impacts of tourism on host communities, thereby enabling tourism managers to carry out better tourism planning. On the other hand, these results extend the knowledge on the links with institutional quality and this allows policy-makers to be aware of more elements upon which to base their decisions regarding this matter.

The existence of synergies between tourism and institutional quality found in this paper implies that if measures are taken to increase quality of institutions (fight against corruption, reduction of bureaucracy, strengthening of the legal system, among others), they can result in a significant improvement in tourist activity. Similarly, economies that opt for a specialization in the tourism sector will find incentives to improve the quality of their institutions; which in turn, may imply a higher quality of life for its inhabitants.

Given the implications of the topic analysed in this work, for future research it could be useful to deepen in several aspects. On the one hand, the specific links of tourism activity with each of the components of institutional quality should be studied. As pointed out in the paper, institutional quality is a very broad concept that includes dimensions such as 
corruption, bureaucracy or law and order. Therefore, it could be interesting to analyse if the links of each of these dimensions with tourism activity are still significant and positive and on which of them the tourism specialization has the greatest impacts. On the other hand, it would also be relevant to carry out a similar study disaggregating the tourism specialization into the specific type of tourism developed. This would allow us to know to what extent the characteristics of tourism show different relationships with the quality of the institutions. Finally, another extension of interest is to analyze if there are significant differences in the results when data are disaggregated at a regional or local level.

\section{REFERENCES}

ACEMOGLU, D.A., JOHNSON, S. and ROBINSON, J.A. (2001): «The colonial origins of comparative development: An empirical investigation», American Economic Review, vol. 91 (5), pp. 1369-1401.

ADES, A. and DI TELLA, R. (1999): «Rents, competition, and corruption», American Economic Review, vol. 89 (4), pp. 982-993.

ADSERA, A., BOIX, C. and PAYNE, M. (2003): «Are you being served? Political accountability and the quality of government», The Journal of Law, Economics and Organization, vol. 19 (2), pp. 445-90.

ALESINA, A., DEVLEESCHAUWER, A., EASTERLY, W., et al. (2003): «Fractionalization», Journal of Economic Growth, vol. 8 (2), pp. 155-194.

ALESINA, A. and GIULIANO, P. (2015): «Culture and institutions», Journal of Economic Literature, vol. 53 (4), pp. 898-944.

ALESINA, A. and LA FERRARA, E. (2005): «Ethnic diversity and economic performance», Journal of Economic Literature, vol. 43 (3), pp. 762-800.

ALESINA, A. and PEROTTI, R. (1996): «Income distribution, political instability and investment», European Economic Review, vol. 40 (6), pp. 1203-1228.

ALONSO, J.A. and GARCIMARTÍN, C. (2013): «The determinants of institutional quality, more on the debate», Journal of International Development, vol. 25 (2), pp. 206-226.

ALTIN, M., MEMILI, E. and SÖNMEZ, S. (2017): «Institutional economics and firm creation in the hospitality and tourism industry: A comparative analysis of developing and developed economies», Tourism Economics, vol. 23 (7), pp. 1381-1397.

AUER, R.A. (2013): «Geography, institutions, and the making of comparative development», Journal of Economic Growth, vol. 18 (2), pp. 179-215.

BARRO, R. and LEE, J-W. (2013): «A new data set of educational attainment in the world, 1950-2010», Journal of Development Economics, vol. 104, pp. 184-198.

BEERLI, A. and MARTÍN, J.D. (2004): «Factors influencing destination image», Annals of Tourism Research, vol. 31 (3), pp. 657-681.

BLAKE, A. (2008): «Tourism and income distribution in East Africa», International Journal of Tourism Research, vol. 10 (6), pp. 511-24.

BRAU, R., DI LIBERTO, A. and PIGLIARU, F. (2011): «Tourism and development: A recent phenomenon built on old (institutional) roots? », The World Economy, vol. 34 (3), pp. 444-472. 
BRUNETTI, A. and WEDER, B. (2003): «A free press is bad news for corruption», Journal of Public Economics, vol. 87 (7), pp. 1.801-1.824.

CASAS JURADO, A.C., SOLER DOMINGO, A. and JAIME PASTOR, V. (2012): «El turismo comunitario como instrumento de erradicación de la pobreza: Potencialidades para su desarrollo en Cuzco (Perú)», Cuadernos de Turismo, n 30, pp. 91-108.

CROES, R. and VANEGAS, M. (2008): «Cointegration and causality between tourism and poverty reduction», Journal of Travel Research, vol. 47 (1), pp. 94-103.

DAHLBERG, S., HOLMBERG, S., ROTHSTEIN, B. et al. (2016): The quality of government basic dataset, version Jan16. University of Gothenburg: The Quality of Government Institute. Retrieved from: http://www.qog.pol.gu.se, doi:10.18157/QoGBasJan16.

DAS, J. and DI RIENZO, C. (2010): «Tourism competitiveness and corruption: a crosscountry analysis». Tourism Economics, vol. 16 (3), pp. 477-492.

DWYER, L., FORSYTH, P. and SPURR, R. (2004): «Evaluating tourisms economic effects: New and old approaches», Annals of Tourism Research, vol. 25 (3), pp. 307317.

DWYER, L. and KIM, C. (2003): «Destination competitiveness: determinants and indicators», Current Issues in Tourism, vol. 6 (5), pp. 369-414.

EASTERLY, W. (2001): «The middle class consensus and economic development», Journal of Economic Growth, vol. 6 (4), pp. 317-335.

ENRIGHT, M.J. and NEWTON, J. (2004): «Tourism destination competitiveness: a quantitative approach», Tourism Management, vol. 25 (6), pp. 777-788.

ENRIGHT, M.J. and NEWTON, J. (2005): «Determinants of tourism destination competitiveness in Asia Pacific: comprehensiveness and universality», Journal of Travel Research, vol. 43 (4), pp. 339-350.

EVANS, P. and RAUCH, P. (2000): «Bureaucratic structure and bureaucratic performance in less developed countries», Journal of Public Economics, vol. 75 (1), pp. 49-71.

FARIA, H.J., MORALES, D.R., PINEDA, N. et al. (2012): «Can capitalism restrain public perceived corruption? Some evidence», Journal of Institutional Economics, vol. 8 (4), pp. 511-535.

FLETCHER, J.E. and ARCHER, B. (1991): «The development and application of multiplier analysis», in Cooper, C. (Ed.) Progress in Tourism, Recreation and Hospitality Management, vol. 3. London, Belhaven Press, pp. 28-47.

FORTUNATO, P. and PANIZA, U. (2015): «Democracy, education and the quality of government», Journal of Economic Growth, vol. 20 (4), pp. 333-363.

GLAESER, E.L. and SAKS, R.E. (2006): «Corruption in America», Journal of Public Economics, vol. 90 (6-7), pp. 1.053-1.072.

GOOROOCHURN, N. and SUGIYARTO, G. (2005): «Competitiveness indicators in the travel and tourism industry», Tourism Economics, vol. 11 (1), pp. 25-43.

HALL, M. and PAGE, S. (2006): The geography of tourism and recreation-Environment, place and space (3rd ed.). London, Routledge.

HIGGINS-DESBIOLLES, F. (2006): «More than an "industry": the forgotten power of tourism as a social force», Tourism Management, vol. 27 (6), pp. 1.192-1.208.

HUNT, J. (1975): «Image as a factor in tourism development», Journal of Travel Research, vol. 13 (3), pp. 1-17. 
HUNTINGTON, S. (1968): Political order in changing societies. New Haven, Yale University Press.

INTERNATIONAL UNION OF TOURISM ORGANIZATIONS (IUTO) (1974): «The role of the state in tourism», Annals of Tourism Research, vol. 1 (3), pp. 66-72.

ISLAM, R. and MONTENEGRO, C. (2002): What determines the quality of institutions? Policy, Research working paper series vol. WPS2764. Washington DC, World Bank. Retrieved from: http://documents.worldbank.org/curated/en/416091468766754963/ What-determines-the-quality-of-institutions

IVANOV, S. and WEBSTER, C. (2007): «Measuring the impact of tourism on economic growth», Tourism Economics, vol. 13 (3), pp. 379-388.

IVANOV, S. and WEBSTER, C. (2013): «Globalization as a driver of destination competitiveness». Annals of Tourism Research, vol. 43, pp. 624-650.

KADIYALI, V. and KOSOVÁ, R. (2013): «Inter-industry employment spillovers from tourism inflows», Regional Science and Urban Economics, vol. 43 (2), pp. 272-281.

KIM, S. and KIM, D. (2012): «Does government make people happy?: Exploring new research directions for government's roles in happiness», Journal of Happiness Studies, vol. 13 (5), pp. 875-899.

LA PORTA, R., LOPEZ-DE-SILANES, F., SHLEIFER, A. et al. (1999): «The quality of government», Journal of Law, Economics and Organization, vol. 15 (1), pp. 222-279.

LEATHERMAN, J. and MARCOUILLER, D. (1996): «Income distribution characteristics of rural economic sectors: implications for local development policy», Growth and Change, vol. 27 (4), pp. 434-59.

LEATHERMAN, J. and MARCOUILLER, D, (1999): «Moving beyond the modelling of regional economic growth: A study of how income is distributed to rural households», Economic Development Quarterly, vol. 13 (1), pp. 38-45.

LEE, C-K. and KANG, S.(1988): «Measuring earnings inequality and median earnings in the tourism industry», Tourism Management, vol. 19 (4), pp. 341-348.

LEE, S. (2015): «Research note: Quality of government and tourism destination competitiveness», Tourism Economics, vol. 21 (4), pp. 881-888.

LEITE, C.A. and WEIDMANN, J. (1999): Does mother nature corrupt? Natural resources, corruption, and economic growth, IMF Working Paper vol. 99/85. Washington DC, International Monetary Fund. Retrieved from: https:/www.imf.org/en/Publications/ WP/Issues/2016/12/30/Does-Mother-Nature-Corrupt-Natural-Resources-Corruptionand-Economic-Growth-3126.

LEJÁRRAGA, I. and WALKENHORST, P. (2013): «Economic policy, tourism trade and productive diversification», International Economics, vol. 135-136, pp. 1-12.

MARCOUILLER, D.W., KIM, K-K. and DELLER, S.C. (2004): «Natural amenities, tourism and income distribution», Annals of Tourism Research, vol. 31 (4), pp. 1.0311.050 .

MELGAR, N., ROSSI, M. and SMITH, T.W. (2010): «The perception of corruption», International Journal of Public Opinion Research, vol. 22 (1), pp. 120-131.

NKYI, E. and HASHIMOTO, A. (2014): «Human rights issues in tourism development», in Sharpley, R. and Telfer, D. (Eds.): Tourism and development: concepts and issues. Bristol, Channel View Publications, pp. 378-399. 
OECD (1991): Tourism policy and international reports (Annual reports). Paris, OECD.

OH, H., FIORE, A. and JEONG, M. (2007): «Measuring experience economy concepts: tourism applications», Journal of Travel Research, vol. 46 (2), pp. 119-132.

PABLO-ROMERO, M.P. and MOLINA, J.A. (2013): «Tourism and economic growth: A review of empirical literature», Tourism Management Perspectives, vol. 8, pp. 28-41.

POPRAWE, M. (2015): «A panel data analysis of the effect of corruption on tourism», Applied Economics, vol. 47 (23), pp. 2.399-2.412.

RIGOBON, R. and RODRIK, D. (2004): Rule of law, democracy, openness, and income: estimating the interrelationships, NBER Working Paper vol. 10750. Cambridge, MA, National Bureau of Economic Research, Inc.

SINCLAIR, M.T. (1998): «Tourism and economic development: a survey», Journal of Development Studies, vol. 34 (5), pp. 1-51.

TAYLOR, C.L. and MICHAEL, C.H. (1972): World handbook of political and social indicators, Ann Arbor, MI, ICPSR.

TREISMAN, D. (2000): «The causes of corruption: A cross-national study», Journal of Public Economics, vol. 76 (3), pp. 399-457.

TREISMAN, D. (2007): «What have we learned about the causes of corruption from ten years of cross-national empirical research? », Annual Review of Political Science, vol. 10, pp. 211-244.

UYSAL, M., SIRGY, M.J., WOO, E. et al. (2016): «Quality of life (QOL) and well-being research in tourism», Tourism Management, vol. 53, pp. 244-261.

WAGNER, J. (1997): «Estimating the economic impacts of tourism». Annals of Tourism Research, vol. 24 (3), pp. 592-608.

WALL, G. and MATHIESON, A. (2006): Tourism: Changes, impacts, and opportunities. New York, Pearson Prentice Hall.

WATTANAKULJARUS, A. and COXHEAD, I. (2008): «Is tourism-based development good for the poor? A general equilibrium analysis for Thailand», Journal of Policy Modelling, vol. 30 (6), pp. 929-955.

WORLD TOURISM ORGANIZATION (2005): Indicators of sustainable development for tourism destinations: A guidebook. Madrid, UNWTO.

WORLD TOURISM ORGANIZATION (2010): Tourism Satellite Account: Recommended methodological framework 2008. New York, United Nations.

WORLD TOURISM ORGANIZATION (2015): Tourism and the sustainable development goals. Madrid, UNWTO.

WORLD TRAVEL AND TOURISM COUNCIL AND OXFORD ECONOMICS (WTTC) (2016): Travel and tourism economic impact research methodology. Oxford, UK, Oxford Economics. Retrieved from: http://www.wttc.org/-/media/files/reports/economic\%20impact\%20research/2016\%20documents/2016methodology\%20final.pdf

YUAN, Y.H. and WU, C.K. (2008): «Relationships among experiential marketing, experiential value, and customer satisfaction», Journal of Hospitality and Tourism Research, vol. 32 (3), pp. 387-410. 


\section{APPENDIX 1}

Table A1

COUNTRIES

\begin{tabular}{|lll|}
\hline Albania & Gambia (1) & Norway \\
Algeria (1) & Ghana & Pakistan \\
Argentina & Greece & Panama \\
Australia & Guatemala & Papua New Guinea \\
Austria & Guyana (1) & Paraguay \\
Bangladesh & Haiti & Peru \\
Belgium & Honduras & Philippines \\
Benin & Hungary & Poland \\
Bolivia & Iceland & Portugal \\
Botswana & India & Romania \\
Brazil & Indonesia & Rwanda \\
Bulgaria & Iran & Senegal \\
Burundi & Ireland & Sierra Leone \\
Cambodia & Israel & South Africa \\
Cameroon & Italy & Spain \\
Canada & Jamaica (1) & Sri Lanka \\
Central African Republic & Jordan & Swaziland \\
Chile & Kenya & Sweden \\
China & Lao & Syrian Arab Republic \\
Colombia & Lesotho & $(1)$ \\
Congo, Democratic Republic & Luxembourg & Tanzania \\
Costa Rica & Malawi & Thailand \\
Côte D'Ivoire & Malaysia & Tunisia \\
Cyprus & Mali & Turkey \\
Denmark & Mexico & Uganda \\
Dominican Republic & Mongolia & United Kingdom \\
Ecuador & Morocco & United States Of \\
El Salvador & Mozambique & America \\
Fiji & Nepal & Uruguay \\
Finland & Netherlands & Venezuela \\
France & Nicaragua & Viet Nam \\
& & Zambia \\
\hline No: & & \\
\hline & &
\end{tabular}

Note: (1) Data available only for the first period (1995-2004). 


\section{APPENDIX 2}

Table A2

\section{LEGAL ORIGIN}

\begin{tabular}{|lll|}
\hline Common Law & French Commercial Law & Panama \\
Australia & Algeria & Paraguay \\
Bangladesh & Argentina & Peru \\
Botswana & Belgium & Philippines \\
Canada & Benin & Portugal \\
Cyprus & Bolivia & Rwanda \\
Fiji & Brazil & Senegal \\
Gambia & Burundi & Spain \\
Ghana & Cameroon & Syrian Arab Republic \\
Guyana & Central African Republic & Tunisia \\
India & Chile & Turkey \\
Ireland & Colombia & Uruguay \\
Israel & Congo, Democratic Republic & Venezuela \\
Jamaica & Costa Rica & Socialist Law \\
Kenya & Cote D'Ivoire & Albania \\
Lesotho & Dominican Republic & Bulgaria \\
Malawi & Ecuador & Cambodia \\
Malaysia & El Salvador & China \\
Nepal & France & Hungary \\
Pakistan & Greece & Lao \\
Papua New Guinea & Guatemala & Mongolia \\
Sierra Leone & Haiti & Poland \\
South Africa & Honduras & Romania \\
Sri Lanka & Indonesia & Viet Nam \\
Swaziland & Iran, Islamic Republic Of & German Law \\
Tanzania, United Republic Of & Italy & Austria \\
Thailand & Jordan & Scandinavian \\
Uganda & Luxembourg & Commercial Law \\
United Kingdom & Mali & Denmark \\
United States Of America & Mexico & Finland \\
Zambia & Morocco & Iceland \\
& Mozambique & Norway \\
& Netherlands & Sweden \\
\hline & Nicaragua & \\
\hline & & \\
\hline
\end{tabular}




\section{APPENDIX 3}

Table A3

DESCRIPTIVE STATISTIC

\begin{tabular}{lccccc}
\hline & Mean & Maximum & Minimum & Std. Dev. & Observations \\
\hline ICRG & 5.760 & 9.955 & 1.262 & 2.112 & 159 \\
TS & 3.701 & 11.767 & 0.577 & 2.008 & 179 \\
FRAC & 0.419 & 0.930 & 0.039 & 0.260 & 179 \\
EDUC & 2.292 & 5.640 & 0.095 & 1.406 & 179 \\
DEMOC & 7.117 & 10.000 & 0.500 & 2.696 & 179 \\
FP & 17.355 & 35.900 & 2.000 & 8.943 & 179 \\
OPEN & 76.860 & 335.249 & 22.086 & 42.730 & 158 \\
GDP & $14,630.19$ & $90,792.38$ & 557.953 & $16,076.90$ & 176 \\
GINI & 41.308 & 64.730 & 25.890 & 9.188 & 179 \\
L20 & 6.004 & 9.410 & 1.700 & 2.052 & 179 \\
EF & 60.367 & 81.762 & 36.900 & 9.082 & 179 \\
\hline
\end{tabular}

Notes: ICRG: Quality of institutions; TS: Tourism specialization; FRAC: Ethnic fractionalization; EDUC: Education; DEMOC: Democracy; FP: Freedom of the press; OPEN: International openness; GDP: Income level; GINI: Gini index; L20: Income share held by lowest $20 \%$ of the population; EF: Economic freedom. 


\section{APPENDIX 4}

Table A4.1a

EFFECT OF TOURISM ON QUALITY OF INSTITUTIONS (1995-2004)

\begin{tabular}{|c|c|c|c|c|c|c|c|c|}
\hline \multicolumn{9}{|c|}{ Dependent Variable: Quality of Institutions (ICRG) } \\
\hline & $\mathrm{E}(1)$ & $\mathrm{E}(2)$ & $\mathrm{E}(3)$ & E (4) & $\mathrm{E}(5)$ & E (6) & $\mathrm{E}(7)$ & $\mathrm{E}(8)$ \\
\hline TS & $\begin{array}{l}0.225^{* *} \\
(3.034)\end{array}$ & $\begin{array}{l}0.222^{* * *} \\
(2.975)\end{array}$ & $\begin{array}{l}0.119^{* *} \\
(1.940)\end{array}$ & $\begin{array}{l}0.171^{* * *} \\
(2.611)\end{array}$ & $\begin{array}{l}0.167^{* *} \\
(2.562)\end{array}$ & $\begin{array}{l}0.231^{* * *} \\
(3.664)\end{array}$ & $\begin{array}{l}0.084 \\
(1.450)\end{array}$ & $\begin{array}{l}0.078 \\
(1.355)\end{array}$ \\
\hline
\end{tabular}

Channels:

OPEN $\quad 0.002$

(0.704)

GDP

$0.859^{* * *}$

(4.787)

$\begin{array}{ll}0.669^{* * *} & 0.610^{* * *} \\ (3.751) & (3.932)\end{array}$

GINI

$-0.041^{* * *}-0.045^{* * *}$

$(-2.874)$

(3.553)

L20

$0.191^{* * *} \quad 0.210^{* * *}$

(3.060)

(3.863)

$\mathrm{EF}$

$0.050^{* * *} \quad 0.043^{* *} \quad 0.042^{* *}$

$\begin{array}{lll}(2.634) \quad(2.402) \quad(2.364) & \end{array}$

Control variables:

\begin{tabular}{|c|c|c|c|c|c|c|c|c|}
\hline EDUC*DEMOC & $\begin{array}{l}0.081^{* * *} \\
(6.361)\end{array}$ & $\begin{array}{l}0.081^{* * *} \\
(6.392)\end{array}$ & $\begin{array}{l}0.025 \\
(1.542)\end{array}$ & $\begin{array}{l}0.074^{* * *} \\
(6.646)\end{array}$ & $\begin{array}{l}0.077^{* * *} \\
(6.023)\end{array}$ & $\begin{array}{l}0.070^{* * *} \\
(5.221)\end{array}$ & $\begin{array}{l}0.020 \\
(1.378)\end{array}$ & $\begin{array}{l}0.022 \\
(1.523)\end{array}$ \\
\hline FRAC & $\begin{array}{l}-0.548 \\
(-0.956)\end{array}$ & $\begin{array}{l}-0.555 \\
(-0.971)\end{array}$ & $\begin{array}{l}-0.086 \\
(-0.169)\end{array}$ & $\begin{array}{l}-0.632 \\
(-1.170)\end{array}$ & $\begin{array}{l}-0.667 \\
(-1.241)\end{array}$ & $\begin{array}{l}-0.254 \\
(-0.458)\end{array}$ & $\begin{array}{l}-0.023 \\
(-0.049)\end{array}$ & $\begin{array}{l}-0.051 \\
(-0.110)\end{array}$ \\
\hline $\begin{array}{l}\text { COMMON } \\
\text { LAW }\end{array}$ & $\begin{array}{l}-0.193 \\
(-0.413)\end{array}$ & $\begin{array}{l}-0.208 \\
(-0.441)\end{array}$ & $\begin{array}{l}-0.109 \\
(0.320)\end{array}$ & $\begin{array}{l}0.240 \\
(0.603)\end{array}$ & $\begin{array}{l}0.281 \\
(0.707)\end{array}$ & $\begin{array}{l}-0.625 \\
(-1.540)\end{array}$ & $\begin{array}{l}-0.028 \\
(-0.079)\end{array}$ & $\begin{array}{l}0.032 \\
(0.090)\end{array}$ \\
\hline $\begin{array}{l}\text { FRENCH } \\
\text { LAW }\end{array}$ & $\begin{array}{l}-0.543 \\
(-1.220)\end{array}$ & $\begin{array}{l}-0.544 \\
(-1.291)\end{array}$ & $\begin{array}{l}-0.920^{* * *} \\
(-2.843)\end{array}$ & $\begin{array}{l}-0.045 \\
(-0.119)\end{array}$ & $\begin{array}{l}0.060 \\
(0.155)\end{array}$ & $\begin{array}{l}-0.933^{* *} \\
(-2.510)\end{array}$ & $\begin{array}{l}-0.643^{* *} \\
(-1.900)\end{array}$ & $\begin{array}{l}-0.522 \\
(-1.516)\end{array}$ \\
\hline $\mathrm{P}$ & $\begin{array}{l}-0.032 \\
(-1.609)\end{array}$ & $\begin{array}{l}-0.029 \\
(-1.486)\end{array}$ & $\begin{array}{l}-0.039^{* *} \\
(-2.287)\end{array}$ & $\begin{array}{l}-0.033^{*} \\
(-1.825)\end{array}$ & $\begin{array}{l}-0.033^{*} \\
(-1.836)\end{array}$ & $\begin{array}{l}-0.012 \\
(-0.594)\end{array}$ & $\begin{array}{l}-0.023 \\
(-1.330)\end{array}$ & $\begin{array}{l}-0.023 \\
(-1.372)\end{array}$ \\
\hline Constant: & $\begin{array}{l}4.739^{* * *} \\
(6.501)\end{array}$ & $\begin{array}{l}4.549^{* * *} \\
(6.689)\end{array}$ & $\begin{array}{l}-1.460 \\
(-0.998)\end{array}$ & $\begin{array}{l}6.462^{* * *} \\
(7.156)\end{array}$ & $\begin{array}{l}3.494^{* * *} \\
(4.451)\end{array}$ & $\begin{array}{l}1.757 \\
(1.331)\end{array}$ & $\begin{array}{l}-0.824 \\
(-0.548)\end{array}$ & $\begin{array}{l}-4.135^{* * *} \\
(-2.763)\end{array}$ \\
\hline N: obse & 82 & 82 & 90 & 92 & 92 & 92 & 92 & 92 \\
\hline 2 & 0.718 & 0.717 & 0.784 & 0.741 & 0.744 & 0.737 & 0.813 & 0.818 \\
\hline
\end{tabular}

Notes: ${ }^{* * * * * * *}$, denote that the coefficients are significant at $1 \%, 5 \%$, and $10 \%$ levels, respectively. The t-statistics are given within parentheses. Column $\mathrm{E}(1)$ shows OLS estimation of equation (1). Columns $\mathrm{E}(2)$ to $\mathrm{E}(6)$ present the SUR estimation of equation (3) for each channel, while considering the system of equations that is comprised of equations (3) and (4). Columns $\mathrm{E}(7)$ and $\mathrm{E}(8)$ show the SUR estimation of equation (5) in the system of equations (5) to (8), while considering the channels that are significant according to the results in $\mathrm{E}(2)$ to $\mathrm{E}(6)$. 
Table A4.2a

EFFECT OF TOURISM ON THE CHANNELS (1995-2004)

\begin{tabular}{lllll}
\hline Dependent variable: Channels & & & \\
\hline & GDP & GINI & L20 & EF \\
\hline TS & $0.108^{* * *}$ & $-1.155^{* * *}$ & $0.263^{* * *}$ & $0.084^{*}$ \\
& $(3.076)$ & $(-2.754)$ & $(2.271)$ & $(1.666)$ \\
EDUC*DEMOC & $0.067^{* * *}$ & $-0.194^{* *}$ & 0.026 & $0.219^{* * *}$ \\
& $(9.001)$ & $(-2.159)$ & $(1.268)$ & $(3.001)$ \\
FRAC & $-0.643^{* *}$ & -3.424 & 0.899 & $-4.854^{*}$ \\
& $(-2.168)$ & $(-0.956)$ & $(1.088)$ & $(-1.665)$ \\
COMMON LAW & 0.011 & $11.063^{* * *}$ & $-2.614 * * *$ & $7.721^{* * *}$ \\
& $(0.054)$ & $(4.459)$ & $(-4.570)$ & $(3.824)$ \\
FRENCH LAW & $0.410^{* *}$ & $11.696^{* * *}$ & $-3.084 * * *$ & $7.180^{* * *}$ \\
& $(2.154)$ & $(2.300)$ & $(-5.813)$ & $(3.836)$ \\
FP & 0.000 & -0.047 & 0.013 & $-0.426^{* * *}$ \\
& $(0.074)$ & $(-0.364)$ & $(0.458)$ & $(-4.070)$ \\
Constant & $7.353^{* * *}$ & $41.794^{* * *}$ & $6.370^{* * *}$ & $59.532^{* *}$ \\
& $(18.825)$ & $(8.899)$ & $(5.881)$ & $(15.590)$ \\
\hline N: observations & 90 & 92 & 92 & 92 \\
$\mathrm{R}^{2}$ & 0.750 & 0.355 & 0.326 & 0.543 \\
\hline
\end{tabular}

Notes: ${ }^{* * * * *, *}$ denote that the coefficients are significant at $1 \%, 5 \%$, and $10 \%$ levels, respectively. The t-statistics are given within parentheses. Columns GDP, GINI, and EF present the SUR estimation of equations (6), (7) and (8) respectively, in the system of equations (5) to (8). Column L20 shows the SUR estimation of equation (7) in the system of equations comprised of equations (5) to (8). 


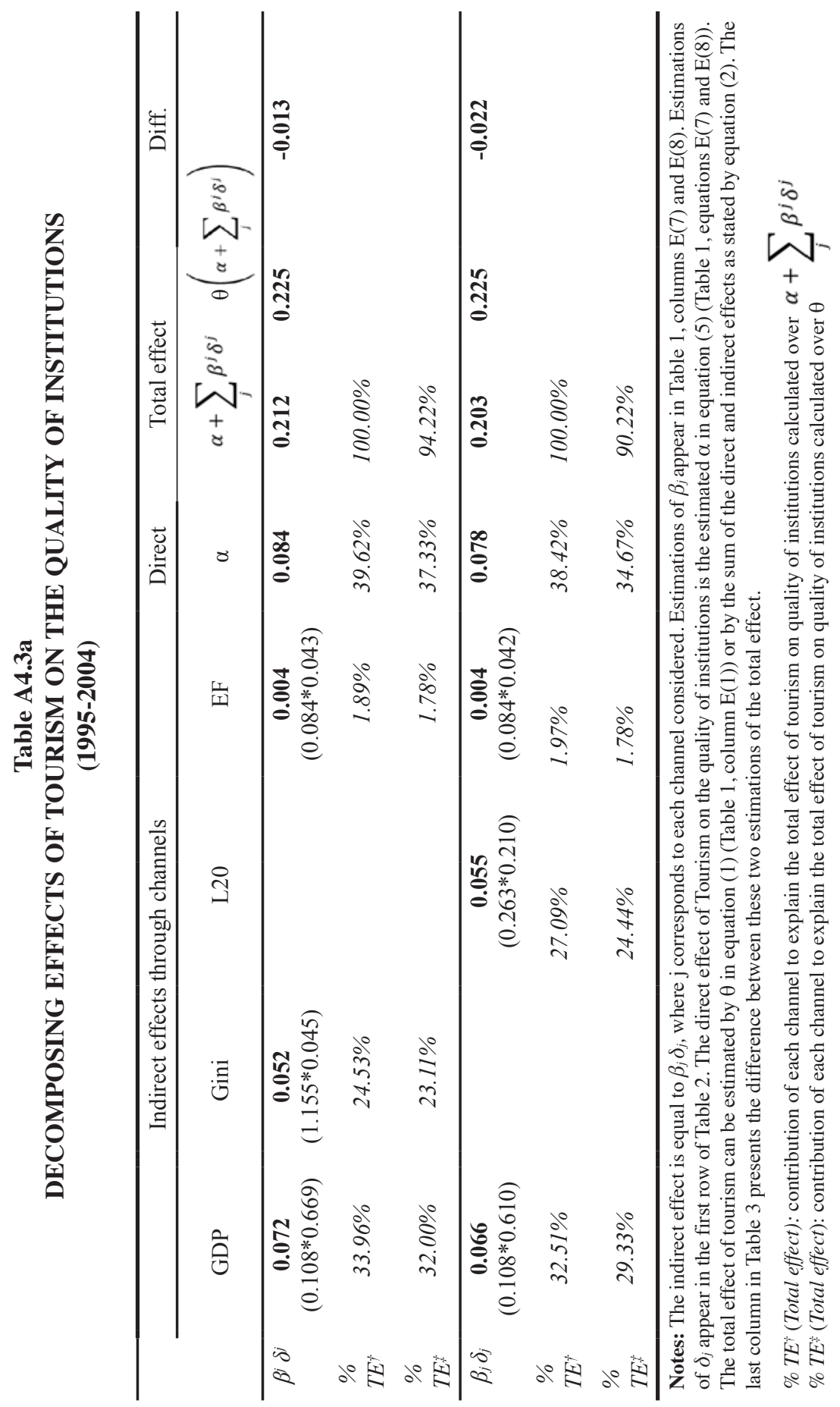


Table A4.1b

EFFECT OF TOURISM ON QUALITY OF INSTITUTIONS

(2005-2014)

\begin{tabular}{lllllllll}
\hline \multicolumn{2}{l}{ Dependent Variable: } & Quality of Institutions (ICRG) \\
\hline \multirow{2}{*}{$\mathrm{TS}$} & $\mathrm{E}(1)$ & $\mathrm{E}(2)$ & $\mathrm{E}(3)$ & $\mathrm{E}(4)$ & $\mathrm{E}(5)$ & $\mathrm{E}(6)$ & $\mathrm{E}(7)$ & $\mathrm{E}(8)$ \\
\hline & $0.162^{* *}$ & $0.146^{*}$ & 0.079 & 0.106 & 0.093 & $0.129^{*}$ & 0.014 & 0.002 \\
& $(2.007)$ & $(1.794)$ & $(1.054)$ & $(1.365)$ & $(1.210)$ & $(1.690)$ & $(0.211)$ & $(0.034)$
\end{tabular}

Channels:

\begin{tabular}{|c|c|c|c|c|c|}
\hline OPEN & $\begin{array}{l}0.004^{*} \\
(1.817)\end{array}$ & & & & \\
\hline GDP & $\begin{array}{l}0.943^{* * *} \\
(4.368)\end{array}$ & & & $\begin{array}{l}0.710^{* * *} \\
(3.554)\end{array}$ & $\begin{array}{l}0.761^{* * *} \\
(3.894)\end{array}$ \\
\hline GINI & & $\begin{array}{l}-0.06^{* * *} \\
(-3.344)\end{array}$ & & $\begin{array}{l}-0.062^{* * *} \\
(-4.177)\end{array}$ & \\
\hline L20 & & $\begin{array}{l}0.300^{* * *} \\
(3.675)\end{array}$ & & & $\begin{array}{l}0.300^{* * *} \\
(4.501)\end{array}$ \\
\hline $\mathrm{EF}$ & & & $\begin{array}{l}0.076^{* * * *} \\
(3.202)\end{array}$ & $\begin{array}{l}0.068^{* * *} \\
(3.137)\end{array}$ & $\begin{array}{l}0.060^{* * *} \\
(2.833)\end{array}$ \\
\hline
\end{tabular}

Control variables:

\begin{tabular}{lllllllll} 
EDUC*DEMOC & $0.074^{* * *}$ & $0.071^{* * *}$ & 0.013 & $0.071^{* * *}$ & $0.076^{* * *}$ & $0.051^{* * *}$ & 0.005 & 0.008 \\
& $(5.739)$ & $(4.983)$ & $(0.720)$ & $(5.680)$ & $(6.131)$ & $(3.489)$ & $(0.308)$ & $(0.555)$ \\
FRAC & -0.807 & -0.952 & -0.210 & -0.815 & -0.838 & -0.724 & -0.249 & -0.241 \\
& $(-1.143)$ & $(-1.280)$ & $(-0.352)$ & $(-1.357)$ & $(-1.414)$ & $(-1.198)$ & $(-0.478)$ & $(-0.470)$ \\
COMMON & 0.287 & 0.430 & 0.323 & $0.738^{*}$ & $0.702^{*}$ & -0.022 & 0.505 & 0.486 \\
LAW & $(0.534)$ & $(0.784)$ & $(0.820)$ & $(1.715)$ & $(1.674)$ & $(-0.053)$ & $(1.365)$ & $(1.342)$ \\
FRENCH & -0.313 & -0.259 & $-0.616^{*}$ & 0.242 & 0.344 & -0.461 & -0.109 & -0.028 \\
LAW & -0.555 & -0.464 & -1.649 & 0.586 & 0.830 & -1.200 & -0.307 & -0.079 \\
& $-0.053^{* *}$ & $-0.05^{*}$ & $-0.077^{* * *}$ & -0.037 & 0.033 & -0.028 & -0.033 & -0.033 \\
FP & $(-2.008)$ & $(-1.833)$ & $(-3.346)$ & $(-1.579)$ & $(-1.402)$ & $(-1.148)$ & $(-1.473)$ & $(-1.511)$ \\
& & & & & & & & \\
Constant: & $4.561^{* * *}$ & $4.249^{* * *}$ & -2.144 & $6.526^{* * *}$ & $2.234^{* *}$ & 0.160 & -2.293 & $-6.693^{* * *}$ \\
& $(5.700)$ & $(4.392)$ & $(-1.253)$ & $(6.660)$ & $(2.234)$ & $(0.101)$ & $(-1.310)$ & $(-3.799)$ \\
\hline N: observations & 77 & 76 & 76 & 77 & 77 & 77 & 76 & 76 \\
$\mathrm{R}^{2}$ & 0.694 & 0.698 & 0.751 & 0.728 & 0.735 & 0.726 & 0.974 & 0.810 \\
\hline
\end{tabular}

Notes: ${ }^{* * * * * * *}$ denote that the coefficients are significant at $1 \%, 5 \%$, and $10 \%$ levels, respectively. The t-statistics are given within parentheses. Column E(1) shows OLS estimation of equation (1). Columns $\mathrm{E}(2)$ to $\mathrm{E}(6)$ present the SUR estimation of equation (3) for each channel, while considering the system of equations that is comprised of equations (3) and (4). Columns $\mathrm{E}(7)$ and $\mathrm{E}(8)$ show the SUR estimation of equation (5) in the system of equations (5) to (8), while considering the channels that are significant according to the results in $\mathrm{E}(2)$ to $\mathrm{E}(6)$. 
TABLE A4.2b

EFFECT OF TOURISM ON THE CHANNELS (2005-2014)

\begin{tabular}{lllll}
\hline Dependent variable: Channels & & & \\
\hline & GDP & GINI & L20 & EF \\
\hline TS & $0.090^{* * *}$ & $-0.592^{*}$ & $0.142^{*}$ & $0.331^{*}$ \\
& $(2.709)$ & $(-1.662)$ & $(1.665)$ & $(1.663)$ \\
EDUC*DEMOC & $0.067 * * *$ & -0.080 & 0.000 & $0.313^{* * *}$ \\
& $(10.296)$ & $(-1.036)$ & $(0.013)$ & $(5.633)$ \\
FRAC & $-0.615^{* *}$ & 0.026 & 0.041 & -2.069 \\
& $(-2.056)$ & $(0.007)$ & $(0.050)$ & $(-0.810)$ \\
COMMON LAW & 0.013 & $7.906 * * *$ & $-1.613 * * *$ & $3.575^{* *}$ \\
& $(0.066)$ & $(3.217)$ & $(-2.850)$ & $(2.031)$ \\
FRENCH LAW & 0.275 & $9.073^{* * *}$ & $-2.221^{* * *}$ & 1.732 \\
& $(1.436)$ & $(3.975)$ & $(-4.226)$ & $(1.060)$ \\
FP & $0.023^{* *}$ & 0.200 & -0.050 & $-0.271^{* * *}$ \\
& 1.932 & 1.397 & -1.516 & -2.635 \\
Constant & $7.008^{* * *}$ & $34.232^{* * *}$ & $8.007 * * *$ & $57.015^{* * *}$ \\
& $(16.894)$ & $(6.896)$ & $(7.007)$ & $(16.041)$ \\
\hline N: observations & 86 & 87 & 87 & 87 \\
$\mathrm{R}^{2}$ & 0.747 & 0.307 & 0.245 & 0.649 \\
\hline
\end{tabular}

Notes: ${ }^{* * * * * * *}$ denote that the coefficients are significant at $1 \%, 5 \%$ and $10 \%$ levels respectively. The t-statistics are given within parentheses. Columns GDP, GINI and EF present the SUR estimation of equations (6), (7) and (8) respectively, in the system of equations (5) to (8). Column L20 shows the SUR estimation of equation (7) in the system of equations comprised of equations (5) to (8). 


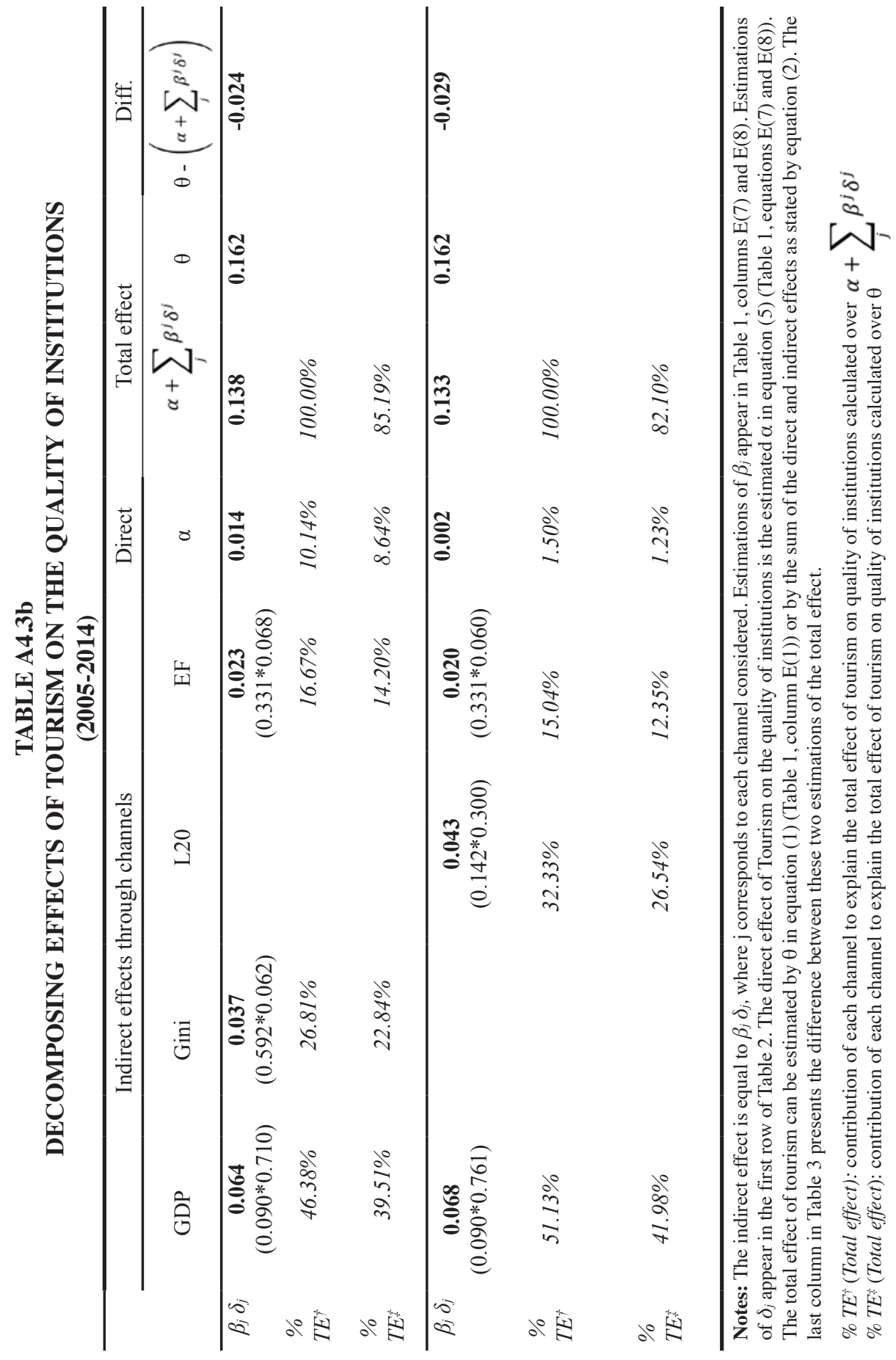


